\title{
Multivariate morphometric study for species differentiation in two congeneric schizothoracids, Schizothorax niger Heckel 1838 and Schizothorax esocinus Heckel 1838 from River Jhelum Kashmir
}

\author{
TASADUQ HUSSAIN SHAH, SOBIYA GUL AND BISMA KHAN \\ Division of Fisheries Resource Management, Faculty of Fisheries, Sher-e-Kashmir University of Agricultural Sciences \\ and Technology of Kashmir (SKUAST-K), Rangil, Ganderbal-190 006, Jammu and Kashmir, India \\ e-mail:tasaduqs@gmail.com; tasaduqshah@skuastkashmir.ac.in
}

\begin{abstract}
Principal component and discriminant analyses were used to investigate morphological differences between Schizothorax niger Heckel 1838 and Schizothorax esocinus Heckel 1838 from River Jhelum, Kashmir, India. The purpose of this study was to identify the two species correctly and assign them into distinct genetic groups. Seven morphometric measurements (body weight, standard length, total length, head length, body depth, pre-dorsal length and caudal fin length) were studied in 100 fish specimens. All the studied morphometric characters reported higher mean values $(\mathrm{p}<0.01)$ in $S$. niger. The use of multivariant techniques such as principal component analysis, showed that the differences between the species resulted mainly from body weight, standard length, pre-dorsal length, head length, total length and caudal fin length. The stepwise discriminant analysis revealed that morphometric traits namely, standard length, pre-dorsal length and caudal fin length were the three most important variables to clearly distinguish the two species. Cross validation test using leave-one-out procedure indicated that $89 \%$ original grouped cases correctly classified into their groups, whereas $89 \%$ of cross validated grouped cases were correctly classified.
\end{abstract}

Keywords: Fish stocks, Morphology, Schizothorax, Snow trout, Variation

\section{Introduction}

The comparisons on the anatomical attributes of organisms have long been considered as the central component of biology. The organisms' descriptions and morphological accounts of the organisms turned out to be the basis underpinning the understanding of life as well as the organisms' classification (Adams et al., 2004). For a variety of quantitative investigations such as on biological shape, shape disparity and covariation of shape with other biotic or abiotic variables or factors, morphometrics can be employed (Webster and Sheets, 2010). The use of morphology emerged as a scientific discipline in the early $20^{\text {th }}$ century based on the 'form, shape and function' of species' morphologies (Russell, 1916; Thompson, 1991). From then until now, this approach has been applied in many studies and has been suggested as a useful tool for better understanding the mechanisms promoting species coexistence as well as for inferring the ecological strategies of species (Gatz, 1979; Bellwood et al., 2006). Morphometric variation may be applicable for studying short term, environmentally induced variation geared towards successful fisheries management and also provide a basis for stock structure (Murta, 2002). To quantify morphometric variables, the use of multivariate techniques such as discriminant analyses and principal components is receiving increased attention in stock identification (Kusznierz et al., 2008; Bektas and Belduz, 2009).

The schizothoracids commonly known as snow trouts are members of the family Cyprinidae, consisting of 15 genera and over 100 species all over the world (Mirza, 1991) and are believed to have migrated into lakes and streams of Kashmir from Central Asian watersheds bordered by inner and southern slopes of Hindukush, Karakoram and inner ends of north-western Himalayas and Sulaiman Ranges (Sehgal, 1999). In India, these species are distributed at an elevation of 1180-3000 $\mathrm{m}$ above msl, in the cold waters from Jammu and Kashmir (Sunder and Bhagat, 1979), to Assam and Eastern Himalayas through Bhutan and Sikkim (Jhingran, 1991). The main constraints hindering the growth and population increase of these species are their inherent biological features, such as short growth period and slow growth to maturity (Mir et al., 2012). Based on external morphological characters across the Indian Himalayas, species of this genus are remarkably similar in general morphology and are often difficult to distinguish (Chandra et al., 2012). From time to time, the taxonomy of these fishes has been studied (Negi and Negi, 2010) but a clear picture of their status has not been available till recently in a combined form (Vishwanath, 2010; Chandra et al., 2012). Fishes of the 
genus Schizothorax are identified by morphological and meristic characters, relying mainly on skin colouration, pigmentation pattern and meristic counts. Schizothorax niger Heckel 1838 has an elongate, fusiform body with a short, blunt and slightly prognathous upper jaw and a dorsal fin exclusively with 6 fin rays. It is chiefly found in lakes. Schizothorax esocinus Heckel 1838 also has an elongate, fusiform body. However, the snout is longer and the upper jaw is either slightly prognathous or both jaws are equal. The number of dorsal fin rays is 7-8 and the fish is a specialised lotic form (Kullander et al., 1999). The maximum reported size is $326 \mathrm{~mm}$ SL (standard length) for $S$. niger and $508 \mathrm{~mm}$ SL for $S$. esocinus (Khan and Sabah, 2013). The present investigation is aimed at examining the morphological variability between $S$. niger and S. esocinus inhabiting River Jhelum, the most important water resource of Kashmir, to provide basis for identification, exploitation, rational management, breeding and conservation of the two commercially most important fish species of Kashmir.

\section{Materials and methods}

Study area

The study was carried out in River Jhelum of Kashmir, India (Fig. 1). River Jhelum is the major water body of Kashmir. It is considered as a lifeline of Kashmir, as it flows through the entire Kashmir Valley from south to north. The water is used for drinking, domestic purposes, irrigation, recreation and generation of electricity. Taking its origin from a perennial spring known as Verinag, the river meanders north-westward from the northern slope of the Pir Panjal Range through the valley to Wular Lake, which controls its flow. It is the second largest fisheries resource of the valley after Wular Lake and harbours a wide variety of fish fauna including both indigenous and exotic species.

\section{Data collection}

One hundred samples, comprising 40 specimens of $S$. niger and 60 specimens $S$. esocinus, were collected from River Jhelum using cast net from October 2017 to March 2018. All fish specimens were transported in insulated boxes to the laboratory where measurements were started immediately to avoid shrinkage of muscles. Since male and female fish could not be differentiated morphologically, sexing of the fish that were sampled was not carried out. Total length (TL) of $S$. niger samples ranged from 199.13 to $325.42 \mathrm{~mm}$ whereas TL of $S$. esocinus ranged from 178.20 to $360.85 \mathrm{~mm}$ respectively (Fig. 2).

Seven morphometric characters, for each sample of fish, were measured with the help of digital vernier calipers (Trusize) to the nearest $0.01 \mathrm{~mm}$, using standard methods as described by Lagler et al. (1962); Laevastu (1965); Lowe-McConnel (1971); Dwivedi and Menezes (1974) and Grant and Spain (1977). All measurements were taken on the left side of the fish by the same person in order to minimise measurement bias. The morphometric characters measured in the present study were: body weight (BW), measured by an analytical balance (Shimadzu) to the nearest $0.01 \mathrm{~g}$, as total weight including gut and gonads; total length (TL) - distance from the tip of the snout to the tip of the caudal fin; standard length (SL) - measured from tip of snout to the base of caudal fin; head length (HL) distance from the tip of the snout to the posterior margin of the operculum; body depth (BD) - maximum vertical length of body (deepest part of the body); pre-dorsal length (PDL) - distance from the tip of the snout to the anterior margin of the base of the dorsal fin and caudal fin

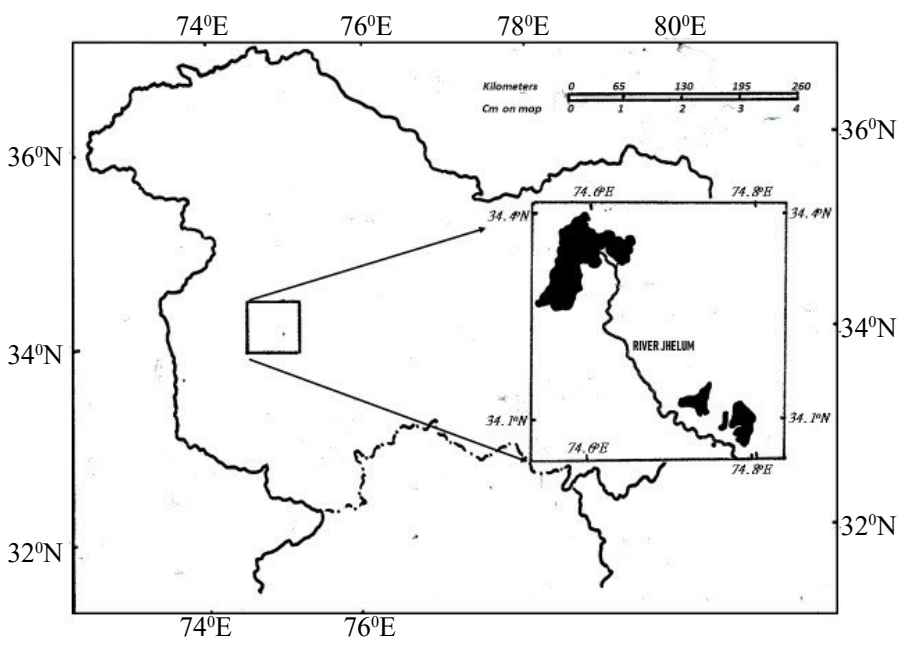

Fig. 1. Study area showing River Jhelum of Jammu and Kashmir India 


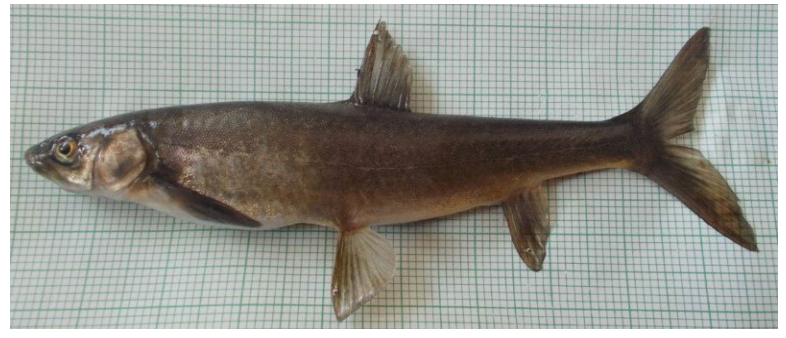

(a)

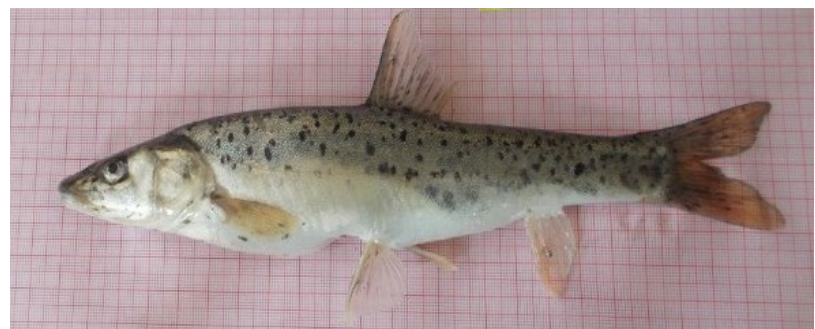

(b)

Fig. 2. Specimens of (a) S. niger and (b) S. esocinus

length (CFL) - distance from the origin of the caudal fin to its maximum length.

The t-test and multivariate statistical methods were used to analyse the data on morphometric measurements (body weight, standard length, total length, head length, body depth, pre-dorsal length and caudal fin length) of the two fish species. Multivariate techniques are widely used to analyse patterns of differentiation between samples and assess similarities. To test for multicollinearity and singularity, principal component analysis was employed. The principal component analysis (PCA) helps to reduce the dimensionality of a data set consisting of a large number of interrelated variables, while retaining the variation present in the data set as much as possible. PCA achieves it by transforming to a new set of variables, the principal components (PCs), which are uncorrelated and which are ordered so that the first few retain most of the variation present in all of the original variables. To minimise size-related dissimilarity, all morphometric variables were amended by adjusting an allometric approach as proposed by Elliott et al. (1995):

$$
\operatorname{Madj}=\mathrm{M}(\mathrm{Ls} / \mathrm{Lo}) \mathrm{b}
$$

where $\mathrm{M}$ is the original measurement, Madj is the size corrected measurement, $\mathrm{L}_{\mathrm{s}}$ is the overall mean of standard length for all samples in each analysis, $\mathrm{L}_{\mathrm{o}}$ is the standard length and $b$ is the slope of the regression of $\log \mathrm{M}$ on $\log \mathrm{L}_{\mathrm{o}}$ using all fish from each group. Significance test of correlating coefficient was applied between transformed variables and standard length to check if the transformation was successful in eliminating the size effects from the entire dataset.

The origins of PCA lie in multivariate data analysis, however, it has a wide range of other applications such as it helps in reduction of morphometric data (Mir et al., 2013a), the redundancy among the variables is decreased (Samaee et al., 2006) and for population differentiation it helps in extracting the independent variables (Samaee et al., 2009). To test the validity of the principal component factor analysis of the data set, Kaiser-Meyer-Olkin measures of sampling adequacy and Bartlett's Test of Sphericity were computed. Cumulative proportion of variance criterion was employed to determine the number of factors to be extracted. To enhance the interpretability of the factor analysis, the varimax method was employed in the rotation of the factor matrix.

Discriminant function analysis (DFA) is a parametric technique to determine which weightings of quantitative variables or predictors best discriminate between two or more than two groups of cases and do so better than chance (Cramer, 2003). The DFA calculates the Percentage of Correctly Classified (PCC) fish. A cross-validation test, using leave-one-out procedure was used. Cross validation using PCC, estimate the expected actual error rates of the classification functions. It gives insight into the group membership and the variables used to predict group membership. To test whether there are differences between the means of identified groups of subjects on a combination of dependent variables, Wilks' lambda was used. The F-to-remove statistic was used to find the relative importance of the morphometric variables in discriminating the two fish populations. By using the tolerance statistic, collinearity among the variables in the discriminant model was evaluated. All analyses were done using SPSS (V23) statistical package.

\section{Results and discussion}

Comparison of morphometric traits between the two species are presented in Table 1. Body weight, standard length, total length, head length, body depth, pre-dorsal length and caudal fin length showed highly significant difference $(p<0.01)$. Higher mean values $(p<0.01)$ in all morphometric traits except for body weight were recorded for $S$. niger. Genetic attributes may be the reason for the superiority exhibited by $S$. niger. The morphometric differentiation of a fish can be influenced by genetic factors, environmental factors and the interaction between them (Mir et al., 2013a). However, morphological characteristics can show high plasticity in response to differences in environmental conditions (Wimberger, 1992). 
Table 1. Basic statistics for the morphometric characters of S. niger and S. esocinus

\begin{tabular}{lllllllll}
\hline \multirow{2}{*}{ Traits } & \multicolumn{3}{c}{ S. niger } & & \multicolumn{3}{c}{ S. esocinus } & \multirow{2}{*}{ p value } \\
\cline { 2 - 3 } & Mean \pm SE & SD & CV\% & & Mean \pm SE & SD & CV\% & \\
BW & $275.61 \pm 4.81$ & 30.84 & 11.19 & & $169.52 \pm 9.51$ & 60.91 & 35.93 & $<0.01$ \\
SL & $237.39 \pm 3.89$ & 24.95 & 10.51 & & $214.35 \pm 4.50$ & 28.84 & 13.45 & $<0.01$ \\
TL & $275.610 \pm 4.81$ & 30.84 & 11.90 & & $241.54 \pm 4.83$ & 30.93 & 12.80 & $<0.01$ \\
HL & $43.89 \pm 0.93$ & 5.95 & 13.56 & & $38.49 \pm 1.52$ & 9.79 & 25.44 & $<0.01$ \\
BD & $48.50 \pm .73$ & 4.72 & 9.74 & & $39.74 \pm 1.32$ & 8.48 & 21.60 & $<0.01$ \\
PDL & $116.66 \pm 1.89$ & 12.14 & 10.41 & & $109.89 \pm 2.99$ & 19.16 & 17.28 & $>0.01$ \\
CFL & $51.59 \pm 1.17$ & 7.53 & 14.6 & & $37.48 \pm 1.573$ & 10.07 & 26.67 & $<0.01$ \\
\hline
\end{tabular}

In Nile tilapia strains, genetic variation in weights and body yields were reported (Diodatti et al., 2008). In a similar study, Turan (2004) reported that phenotypic and genetic differentiation may occur among fish populations, which may be recognisable as a basis for separation and management of distinct populations. The variations in various morphometric parameters of the two species were statistically significant and thus can be regarded as different species (Yousuf, 1996; Kullander et al., 1999). The most important differences in body shape are related to body elongation or shortening, thus leads to large differences in body height and caudal peduncle length among the species (Cavalcanti et al., 1999).

In the principal component analysis, the determinant of the correlation matrix (0.001) we find numerous correlations which were more than 0.00001 (which is the standard), while computed anti-image correlations showed that partial correlations were low, indicating that the true principal component factors existed in the data. It was tested by Kaiser-Meyer-Olkin measure of sampling adequacy studied from the diagonal of partial correlation which revealed the proportion of the variance in the body measurements caused by the underlying factor. The value of 0.874 , obtained in the present study was found to be sufficiently high for all the body traits. Bartlett's Test of Sphericity tested the overall significance of the correlation matrix for the morphometric traits of the two congeneric fish species which provided support for the validity of factor analysis of the data set $\left(\chi^{2}=694.54\right.$; $\left.p<0.01\right)$ (Table 2). The communalities, which represent the proportion of the variance in the original variables that is accounted for by the factor solution ranged from 0.765 to 0.983 . The estimates of the residual correlation matrix were found to be low enough.

After varimax rotation of the factor axes, three principal components were extracted which accounted for $92.13 \%$ of the total variance of the original seven morphological variables (Table 3). The first principal component (PC1), explained $80.27 \%$ of the total variation, with highest loadings on bodyweight, total length and

Table 2. Kaiser-Meyer-Olkin Measure and Bartlett's Test of Sphericity for the two species

\begin{tabular}{lll}
\hline Kaiser-Meyer-Olkin Measure of Sampling Adequacy. & & 0.874 \\
\hline Bartlett's Test of Sphericity & Approx. $\chi^{2}$ & 694.54 \\
& df & 21 \\
& Sig. & 0.000 \\
\hline
\end{tabular}

Table 3. Explained variation associated with rotated factors along with factor loadings and communality for the morphometric measurements of S. niger and S. esocinus

\begin{tabular}{lllll}
\hline Variables & PC1 & PC2 & PC3 & Communality \\
\hline TL & $0.700^{*}$ & 0.386 & 0.549 & 0.941 \\
SDL & $0.739^{*}$ & 0.511 & 0.385 & 0.956 \\
HL & 0.278 & $0.799^{*}$ & 0.464 & 0.931 \\
BD & 0.672 & 0.438 & 0.349 & 0.765 \\
CFL & 0.358 & 0.336 & $0.861^{*}$ & 0.983 \\
BW & $0.897^{*}$ & 0.271 & 0.254 & 0.942 \\
PDL & 0.523 & $0.782^{*}$ & 0.213 & 0.931 \\
Eigen value & 5.619 & 0.463 & 0.367 & \\
Percent variance & 80.277 & 6.607 & 5.248 & \\
Cumulative \% & 80.277 & 86.244 & 92.132 & \\
\hline
\end{tabular}

${ }^{*}$ Values represent highest loadings 
standard length, whereas pre-dorsal length and head length had the highest loadings on PC2 explaining total variation of $6.607 \%$, while PC3 was characterised by caudal fin length (Table 3). This is an indication that the differences between the two fish populations resulted mainly from body width, pre-dorsal length, head length, total length, standard length and caudal fin length. Such variation in morphology is commonly due to the isolation of portions of a population within local habitat conditions. A sufficient degree of isolation may result in notable phenotypic and genetic differentiation among fish populations within a species, as a basis for separation and management of distinct populations (Turan, 2004). Such differentiation can occur through different processes. For example, reproductive isolation between different stocks of fishes may arise by homing to different spawning areas (Hourston, 1982) or by hydrographic features, which reduce or prevent migration between areas (Iles and Sinclair, 1982). The levels of significance vary with features which indicate that different organs grow differently. Size differences might be attributed to the variation of environmental factors, particularly water temperature and food availability (Hossain and Ohtomi, 2010). Similar results have been reported by Hossain et al. (2015) for three populations of Rhinomugil corsula. Hossain et al. (2010) also reported significant differences $(\mathrm{p}<0.05$ or $<0.001)$ in four (Maximum Body Height, Pre-orbital Length, Peduncle Length and Maxillary Barbel Length) of 9 morphometric variations in Labeo calbasu populations collected from the Jamuna, the Halda and a hatchery in Bangladesh. Many other authors have also reported similar results like Parvej et al. (2014) in Eutropiichthys vacha; Siddik et al. (2016) in Sillaginopsis panijus; Wagle et al. (2015) in Schizothorax richarsonii and Esmaeili et al. (2011) in Alburnoides qanati. Fagbuaro et al. (2015) reported significant differences in Clarius gariepinus from Nigeria; differences were attributed to food, environmental conditions and type of habitat. Morphometric differentiation between the samples in the head characters may reflect differential habitat use as well as differences in the feeding regimes (Gatz, 1979). Gupta et al. (2018) reported similar results in five fish species of subfamily Barbinae from the Ganga river system. The dissimilarity of the confirmation for divergence among species probably reflects our use of a different set of characters in the traditional methods, which incorporated a different set of measurements. Fish show more noteworthy variation in morphometric attributes both intraspecific and between species when compared to other vertebrates and are more disposed to ecological changes (Allendorf et al., 1987; Wimberger, 1992). Mallet (1995) describes species as identifiable 'morphological and genotypic clusters'. Morphometric characters are developed from the combination of genotypic and environmental factors, and they are governed by natural selection (Dobzhansky, 1970). Therefore, to authenticate the morphometric differences and for an enhanced perceptive about these examined species, genetic level studies can be performed. The large difference in weight could be due to the density of fish stock and water quality (EcoCostas, 2006).

Organisms are capable of making adaptations that enable them to survive and fishes, like other organisms exhibit similar characteristics. During the developmental history or ontogeny of an organism, its morphology is greatly influenced by its environment, enabling them to survive and fishes, like other organisms exhibit similar characteristics (Nacua et al., 2010).

The stepwise discriminant analysis showing Wilks' lambda values, probability and tolerance statistics are presented in Table 4. When the three most important morphometric traits for separating the two species namely, standard length, pre-dorsal length and caudal fin length, were selected, Wilks' lambda dropped to 0.486 with a significant difference between the two species $(\mathrm{F}=4.538$; $\mathrm{p}<0.001)$. The tolerance values obtained ( 0.174 to 0.454$)$ were greater than 0.1 indicating that there was no collinearity problem among the three most discriminating morphometric variables. The discriminant analysis also showed the high discriminating power of fish body related characters, similar to the results obtained in principal component analysis. Eighty nine percent of original grouped cases correctly classified into their groups; where as $89 \%$ of cross-validated grouped cases were correctly classified (Table 5). Similar results were obtained by Mir et al. (2013b) in S. plagiostomus between Dal Lake and River Lidder populations as well as by Gul et al. (2019) in riverine and lacustrine populations of $S$. niger from Kashmir, India. Mir et al. (2014) was able to classify $83.4 \%$ of $S$. curvifrons individuals into their respective groups by DFA, indicating slight intermingling among the populations. In another study, $86.6 \%$ individuals were correctly classified into their respective groups by DFA in S. richardsonii (Mir et al., 2013a). Pollar et al. (2007) reported that the discriminant analysis showed 95.6\% of Tor tambroide individuals correctly classified into their groups. Morphometric variation is often related to behavioural or ontogenetic differences. Adaptation involves natural selection of those characters that improve the chance for survival and reproduction of individuals. Local environments vary, leading to selection for different characters in different areas. Differences in selected characters are maintained through reproductive isolation among groups (Cadrin, 2004). 
Table 4. Morphometric characters selected by stepwise discriminant analysis to separate $S$. niger and S. esocinus

\begin{tabular}{lllll}
\hline Variables & Tolerance & F to Remove & p value & Wilks' $\lambda$ \\
\hline CFL & 0.454 & 41.993 & 0.000 & 0.667 \\
PDL & 0.192 & 13.081 & 0.000 & 0.527 \\
SDL & 0.174 & 4.538 & 0.000 & 0.486 \\
\hline
\end{tabular}

Table 5. Classification results for the discriminant analysis (Species $1.00=$ S. esocinus; $2.00=$ S. niger)

\begin{tabular}{|c|c|c|c|c|c|}
\hline & & Groups & Pre & ership & Total \\
\hline & & & 1.00 & 2.00 & \\
\hline Original & Count & 1.00 & 52 & 8 & 60 \\
\hline & & 2.00 & 3 & 37 & 40 \\
\hline & $\%$ & 1.00 & 86.7 & 13.3 & 100.0 \\
\hline & & 2.00 & 7.5 & 92.5 & 100.0 \\
\hline Cross-validated & Count & 1.00 & 52 & 8 & 60 \\
\hline & & 2.00 & 3 & 37 & 40 \\
\hline & $\%$ & 1.00 & 86.7 & 13.3 & 100.0 \\
\hline & & 2.00 & 7.5 & 92.5 & 100.0 \\
\hline
\end{tabular}

(a. $89 \%$ of original grouped cases correctly classified; b. $89 \%$ of cross-validated grouped cases correctly classified).

\section{Acknowledgements}

The authors are grateful to the Hon'ble Vice Chancellor, SKUAST-Kashmir and to the Dean, Faculty of Fisheries, SKUAST-Kashmir for providing facilities for carrying out this research work.

\section{References}

Adams, D., Rohlf, F. and Slice, D. 2004. Geometric morphometrics: Ten years of progress following the 'revolution'. Ital. J. Zool., 71(1): 5-16. http://doi.org/10. 1080/11250000409356545.

Allendorf, F., Ryman, N. and Utter, F. 1987. Genetics and fishery management: Past, present and future. In: Ryman, N. and Utter, F. M. (Eds.), Population genetics and fishery management. University of Washington, Washington, USA, p. 1-20.

Bektas, Y. and Belduz, A. O. 2009. Morphological variation among Atlantic horse mackerel, Trachurus trachurus populations from Turkish coastal waters. J. Anim. Vet. Adv., 8(3): 511-517.

Bellwood, D., Wainwright, P., Fulton, C. and Hoey, A. 2006. Functional versatility supports coral reef biodiversity. Proc. R. Soc. B: Biol. Sci., 273(1582): 101-107. http://doi. org/10.1098/rspb.2005.3276.

Cadrin, S. X. 2004. Natural marks-Morphological analyses. In: Cadrin S. X., Friedland K. D. and Waldman J. R. (Eds.), Stock identification methods. Academic Press, Cambridge, Massachusetts, USA, 736 pp.

Cavalcanti, M. J., Monteiro, L. R. and Lopes, P. R. D. 1999. Landmark-based morphometric analysis in selected species of serranid fishes (Perciformes: Teleostei). Zool. Stud., 38(3): 287-294.
Chandra, S., Matura, R., Barat, A. and Singh, B. K. 2012. Development of novel microsatellite markers for threatened species, Schizothorax richardsonii from the Trans-Himalaya, India. Mol. Ecol. Res., 12: 1196-1197.

Cramer, D. 2003. Advanced quantitative data analysis. Open University Press, Buckingham, UK, 208 pp.

Diodatti, F. C., Fonseca, R. T., Freato, T. A., Perez, P. A. and Solis, L. D. 2008. Morphometric measurements in the yield of body component in Nile tilapia (Oreochromis niloticus). Anales de Veterinaria de Murcia, 24: 45-55.

Dobzhansky. 1970. Genetics of the evolutionary process. Columbia University Press, New York, USA, . http:// dx.doi.org/10.3923/pjbs.2007.4383.4390.

Dwivedi, S. N. and Menezes, M. R. 1974. A note on the morphometry and ecology of Brachirus orientalis (Bloch and Schneider) in the estuaries of Goa. Geobios, 1(4): 80-83.

EcoCostas. 2006. Feasibility study for the implementation of a training centre for the cultivation of chame (Dormitator latifrons) in the Cojimies River Estuary, 19 pp (In Spanish).

Elliott, N. G., Haskard, K. and Koslow, J. A. 1995. Morphometric analysis of orange roughly (Hoplostethus atianticus) off the continental slope of Southern Australia. J. Fish Biol., 46: 202-220. https://doi.org/10.1111/j.1095-8649.1995.tb 05962.x.

Esmaeili, H. R., Nazari, N., Saifali, M. and Hosseini, G. A. 2011 Morphometric and meristic comparisons of populations of Qanat tailor fish, Alburnoides qanati in Kor River basin Iran. Iran. J. Anim. Biosyst., 7(1): 1-11.

Fagbuaro, O., Oso, J. A., Olurotimi, M. B. and Akinyemi, O. 2015. Morphometric and meristic characteristics of Clarias gariepinus from controlled and uncontrolled population from southwestern Nigeria. J. Agric. Ecol. Res. Int., 2(1): 39-45. DOI:10.9734/JAERI/2015/11781. 
Gatz, A. J. 1979. Community organization in fishes as indicated by morphological features. Ecology, 60(4): 711-718. http:// doi.org/10.2307/1936608.

Grant, C. J. and Spain, A. V. 1977. Variation in the body shape of three species of Australian mullets (Pisces: Mugilidae) during the course of development. Aust. J. Mar. Freshw. Res., 28(6): 723-738. https://doi.org/10.1071/MF9770723.

Gul, S., Shah, T. H., Bhat, B. A., Ahmed, I., Bhat, F. A., Balkhi, M. H., Ahad, A. and Javeed, H. 2019. Morphological differentiation between riverine and lacustrine populations of snow trout Schizopyge niger (Cyprinidae) from Kashmir using truss morphometry. J. Ichthyol., 59(2): 160-166. http://doi.org/10.1134/S0032945219020085.

Gupta, D., Dwivedi, A. K. and Tripathi, M. 2018. Taxonomic validation of five fish species of subfamily Barbinae from the Ganga river system of northern India using traditional and truss analyses. PLoS ONE, 13(10): e0206031. https:// doi.org/10.1371/ journal.pone.0206031

Hossain, A. R., Nahiduzzaman, Debasish, S., Habiba, K. and Alam 2010. Landmark-based morphometric and meristic variations of the endangered carp, Kalbasu Labeo calbasu, from stocks of two isolated rivers, the Jamuna and Halda, and a hatchery. Zool. Stud., 49(4): 556-563.

Hossain, M. B., Bhowmik, S., Majumdar, P. R., Saha, P. and Rakeb-ul-Islam, M. 2015. Landmark based morphometric and meristic variations in populations of mullet (Rhinomugil corsula). World J. Fish Mar. Sci., 7(1): 12-20.

Hossain, M. Y. and Ohtomi, J. 2010. Growth of the southern rough shrimp Trachysalambria curvirostris (Penaeidae) in Kagoshima Bay, southern Japan. J. Crustac. Biol., 30(1): 75-82.

Hourston, A. S. 1982. Homing by Canada's west coast herring to management units and divisions as indicated by tag recoveries. Can. J. Fish. Aquat. Sci., 39: 1414-1422.

Iles, T. D. and Sinclair, M. 1982. Atlantic herring stock discreteness and abundance. Science, 215: 627-633. DOI: 10.1126/science.215.4533.627.

Jhingran, V. G. 1991. Fish and fisheries of India. Hindustan Publishing Corporation, India. 727 pp.

Khan, M. A. and Sabah. 2013. Length-weight and length-length relationship for five fish species from Kashmir Valley. J. Appl. Ichthyol., 29(1): 283-284. https://doi.org/10.1111/ j.1439-0426.2012.02061.x.

Kullander, S. O., Fang. F., Delling, B. and Ahlander, E. 1999. The fishes of the Kashmir Valley. In: Nyman, L. (Ed.), River Jhelum, Kashmir Valley, Impact on the aquatic environment. Swedmar, Sweden, p. 100-167.

Kusznierz, J., Kotusz, J., Kazak, M., Popiolek, M. and Witkowski, A. 2008. Remarks on the morphological variability of the Arctic charr, Salvelinus alpinus (L.) from Spitsbergen. Pol. Polar Res., 29(3): 227-236.
Laevastu, T. 1965. Manual of methods in fisheries biology research on fish stocks. FAO Manuals in Fisheries Science No. 4, Food and Agriculture Organisation of the United Nations, Rome, Italy, p. 1-51.

Lagler, K. F., Bardach, J. E. and Miller, R. R. 1962. Ichthyology (The study of fishes). John Wiley and Sons, New York, USA, $545 \mathrm{pp}$.

Lowe-McConnell, R. H. 1971. Identification of freshwater fishes. In: Ricker, W. E. (Ed.), Methods of assessment of fish production in freshwaters. Blackwell Scientific, Oxford and Edinburg, UK, p. 45-81.

Mallet, J. 1995. A species definition for the modern synthesis Trends in Ecology and Evolution, 10: 294-299. 10.1016/ 0169-5347(95)90031-4.

Mir, F. A., Mir, J. I. and Chandra, S. 2013a. Phenotypic variation in the snowtrout Schizothorax richardsonii (Gray, 1832) (Actinopterygii: Cypriniformes: Cyprinidae) from the Indian Himalayas. Contrib. Zool., 82(3): 115-122. DOI:10. 1163/18759866-08203001

Mir, F. A., Mir, J. I., Patiyal, R. S. and Chandra, S. 2013b. Pattern of morphometric differentiation among three populations of snowtrout, Schizothorax plagiostomus (Actinopterygii: Cypriniformes: Cyprinidae), from Kashmir Himalaya using Truss network system. Acta Ichthyologica et Piscatoria, 43(4): 277-284. http://doi.org/10.3750/AIP2013.43.4.03.

Mir, F. A., Mir, J. I. and Chandra, S. 2014. Detection of morphometric differentiation in Sattar snowtrout, Schizothorax curvifrons (Cypriniformes: Cyprinidae) from Kashmir Himalaya using a truss network system. Int. J. Trop. Biol., 62(1): 119-127.

Mir, J. I., Shabir, R. and Mir, F. A. 2012. Length-weight relationship and condition factor of Schizopyge curvifrons (Heckel 1838) from River Jhelum, Kashmir, India. World J. Fish. Mar. Sci., 4: 325-329. http://doi.org/10.5829/idosi. wjfms.2012.04.03.6315.

Mirza M. R. 1991. A contribution to the systematics of the Schizothoracine fishes (Pisces: Cyprinidae) with the description of three new tribes. Pak. J, Zool., 23: 339-341.

Murta, A. G. 2002. Morphological variation of horse mackerel (Trachurus trachurus) in the Iberian and North African Atlantic: Implications for stock identification. ICES $J$. Mar. Sci., 57(4): 1240-1248. http://doi.org/10.1006/jmsc. 2000.0810 .

Nacua, S., Dorado, E., Torres, M. and Demayo, C. 2010. Body shape variation between two populations of the white goby, Glossogobius giuris (Hamilton and Buchanan). Res. J. Fish. Hydrobiol., 5(1): 44-51.

Negi, R. K and Negi, T. 2010. Analysis of morphometric characters of Schizothorax richardsonii (Gray 1832) from the Uttarkashi District of Uttarakhand State, India J. Biol. Sci., 10(6): 536-540. http://doi.org/10.3923/jbs 2010.536.540. 
Parvej, M. R., Islam, M. R., Minar, M. H., Hossain, M. B. and Tushar, M. R. 2014. Landmark-based morphometric and meristic variations of the critically endangered catfish, Eutropiichthys vacha from three different populations in Bangladesh. World J. Fish Mar. Sci., 6(4): 378-385. DOI:10.5829/idosi.wjfms.2014.06.04.85117.

Pollar, M., Jaroensutasinee, M. and Jaroensutasinee, K. 2007. Morphometric analysis of Tor tambroides by stepwise discriminant and neural network analysis. Int. J. Bioeng. Life Sci., 1(9): 106-110.

Russell, E. S. 1916. Form and function: A contribution to the history of animal morphology. E.P. Dutton and Co., New York, USA, 383 pp.

Samaee, S. M., Mojazi-Amiri, B. and Hosseini-Mazinani, S. M. 2006. Comparison of Capoeta capoeta gracilis (Cyprinidae, Teleostei) populations in the south Caspian Sea River basin, using morphometric ratios and genetic markers. Folia Zoologica, 55(3): 323-335.

Samaee, S. M., Patzner, R. A. and Mansour, N. 2009. Morphological differentiation within the population of Siah Mahi, Capoeta capoeta gracilis (Cyprinidae, Teleostei) in a river of the south Caspian Sea basin: A pilot study. J. Appl. Ichthyol., 25: 583-590. https://doi.org/10.1111/ j.1439-0426.2009.01256.x.

Sehgal, K. L. 1999. Coldwater fish and fisheries in the Indian Himalayas; Culture. FAO Fisheries Technical Paper No. 385, Food and Agriculture Organisation of the United Nations, Rome, Italy, 102 pp.

Siddik, M. A. B., Hanif, M. A., Chaklader, M. A., Nahar, M. R. and Fotedar, R. 2016. A multivariate morphometric investigation to delineate stock structure of gangetic whiting, Sillaginopsis panijus (Teleostei: Sillaginidae). SpringerPlus, 5(1): 520. https://doi.org/10.1186/s40064016-2143-3.

Sunder, S. and Bhagat, M. J. 1979. A note on the food of Schizothorax plagiostomus (McClelland) in the Chenab drainage of Jammu Province during 1973-74. J. Inland Fish. Soc. India, 11: 117-118.

Thompson, J. D. 1991. Phenotypic plasticity as a component of evolutionary change. Trends in Ecology and Evolution, 6(8): 246-249. https://doi.org/10.1016/0169-5347(91)90070-E.

Turan, C. 2004. Stock identification of Mediterranean horse mackerel (Trachurus mediterraneus) using morphometric and meristic characters. ICES J. Mar. Sci., 61: 774-781. http://doi.org/10.1016/j.icesjms.2004.05.001.

Vishwanath, W. 2010. Schizothorax richardsonii (errata version published in 2018). The IUCN Red List of Threatened Species 2010: e.T166525A135873256. http://dx.doi.org/ 10.2305/IUCN.UK.2010-4.RLTS.T166525A6228314.en. (Accessed 01 July 2019).

Wagle, S. K., Pradhan, N. and Shrestha, M. K. 2015. Morphological divergence of snow trout (Schizothorax richardsonii, Gray 1932) from rivers of Nepal with insights a morphometric analysis. Int. J. Appl. Sci., Biotechnol., 3(3): 464-47. DOI: https://doi.org/10.3126/ijasbt.v3i3.13123.

Webster, M. and Sheets, H. D. 2010. A practical introduction to Landmark based geometric morphometrics. In: Alroy, J. and Hunt, G. (Eds.), Quantitative methods in paleobiology, The Paleontological Society Papers, vol. 16, Paleontological Society Short Course, 30 October 2010. The Paleontological Society, p. 163-188.

Wimberger, P. H. 1992. Plasticity of fish body shape, the effects of diet development, family and age in two species of Geophagus (Pisces: Cichlidae). Biol. J. Linn. Soc., 45(3): 197-218. https://doi.org/10.1111/j.1095-8312.1992.tb 00640.x.

Yousuf, A. R. 1996. Fishery resource of Kashmir. In: Khan, A. H and Pandit, A. K. (Eds.), Ecology, environment and energy. University of Kashmir, Srinagar, India, p. 75-120. 